DOI: https://doi.org/10.30525/978-9934-26-108-4-16

Nataliya Smentyna

Doctor of Economic Sciences, Associate Professor

Odessa National Economic University

Dmytro Skliar

Postgraduate Student

Odessa National Economic University

\title{
THE TRANSFORMATION OF BUSINESS PROCESS MANAGEMENT IN E-COMMERCE IN THE CONTEXT OF CURRENT BUSINESS DEVELOPMENT TRENDS
}

\section{Summary}

It is important for the improvement of the theory, methodology, and practice of management to identify the main trends in the transformation of e-commerce management tools, problems and prospects for their use, and the characteristics of business processes in this area. At the same time, the analysis of the existing scientific heritage revealed insufficient coverage of the business process management specification in e-commerce under the influence of current trends in economic, technological, and social development as a whole. With this in mind, an attempt has been made to identify the basic characteristics and define the main trends in the transformation of business process management in e-commerce within the context of current business trends. The study reveals that influenced by certain trends, constraints, and new opportunities, modern businesses are increasingly turning their attention to the potential of e-commerce as a highly profitable and dynamic area. As a result, the improvement of business process management in this area is in demand and should become a way for modern companies to build and maintain a competitive advantage at the organizational and management level. The analyzed business trends influence the functioning of economic e-commerce entities, along with the specific characteristics of the current period of e-commerce development highlighted by the author. They allow us to present the relationship between the dynamics and specifics of the development in the past, present, and its potential in the future. These characteristics were considered when shaping directions for change of business process management in e-commerce due to the influence of current business trends.

\section{Introduction}

In the present context of global economic growth, fast-developing ecommerce attracts the attention of both management specialists and scientists specializing in creating scientific and practical tools for business process 
management in specific and promising business areas. Certain specifics characterize this area as a subject to management regarding the operational process and applied management tools. This context highlights the need to develop and implement science-based e-commerce management tools, particularly, at the level of business process management, the configuration of which, in turn, is largely determined by the influence of current business trends on the functioning and development of global and local e-commerce. Thus, the presented problems are closely related to the objectives of research, generalization and structuring of global practices of business process management in e-commerce, identifying the main trends in the transformation of management tools, problems, prospects, and the characteristics of specific business processes in this area [3; 15], which is important for the improvement of the theory, methodology, and practice of e-commerce management and determines the relevance of the research topic. The disclosure of the transformation issues of business process management in e-commerce under the influence of current business trends is based on the study of available sources of empirical data and publications of scientific and methodological nature. In particular, the scientific works by such researchers as V. Apopiy, U. Balyk, D. Bell, A. Bereza, L. Gerstner, N. Dmitrieva, G. Duncan, D. Eymor, V. Zwass, M. Castells, L. Klimchenya, O. Kobelev, D. Kozie, S. Malovichko, E. Savelieva, A. Summer, I. Strelets, L. Stewart, Jan Time, W. Triez, R. Frost, L. Khasis, O. Shaleva and others were used. To summarise the studies mentioned above, it is worth noting that the content of e-business management, e-commerce, and trade is quite fully disclosed. The specifics of e-commerce as an object of management are also described in works by I. Burachek, K. Kendall, V. Klochko, D. Kozier, N. Krivosheeva, E. Melz, N. Tyagunova, and L. Filippova.

The analysis of scientific papers revealed insufficient coverage of the specifics of business process management in e-commerce in the context of the transformation of management approaches under the influence of current business trends. Empirical examples are mostly considered and the experience of major market participants is analyzed $[1 ; 2 ; 6 ; 8 ; 9]$. Instead, little attention is paid to the context and conditions in which this experience was demonstrated.

With this in mind, the research aim is to identify the specifics and determine the main transformation trends in business process management in e-commerce under the influence of current business trends.

\section{Part 1. Drivers of the e-commerce business development}

The trends in today's business environment reflect the nature of external circumstances, forcing modern e-commerce businesses to transform, optimize, and reorganize business processes [14].

The analysis of modern scientific works on business process management in e-commerce allowed us to identify trends that characterize the business 
development processes, affecting the priorities and business process management tools of enterprises of the considered area (Figure 1) [11; 14].

Thus, the trend towards a changing customer experience and increasing demands on the product (service) range and quality is characterized by the fact that digital technologies are constantly changing the end user experience. And the very response of the market and creating a supply of goods and services that may be in demand by the consumer market is the basis for developing a new and unique customer experience. Applying big data analytics can help modern businesses identify and differentiate customer profiles based on faster information delivery than before, improve customer relationships, drive customer engagement, and identify/predict their behavior [10].

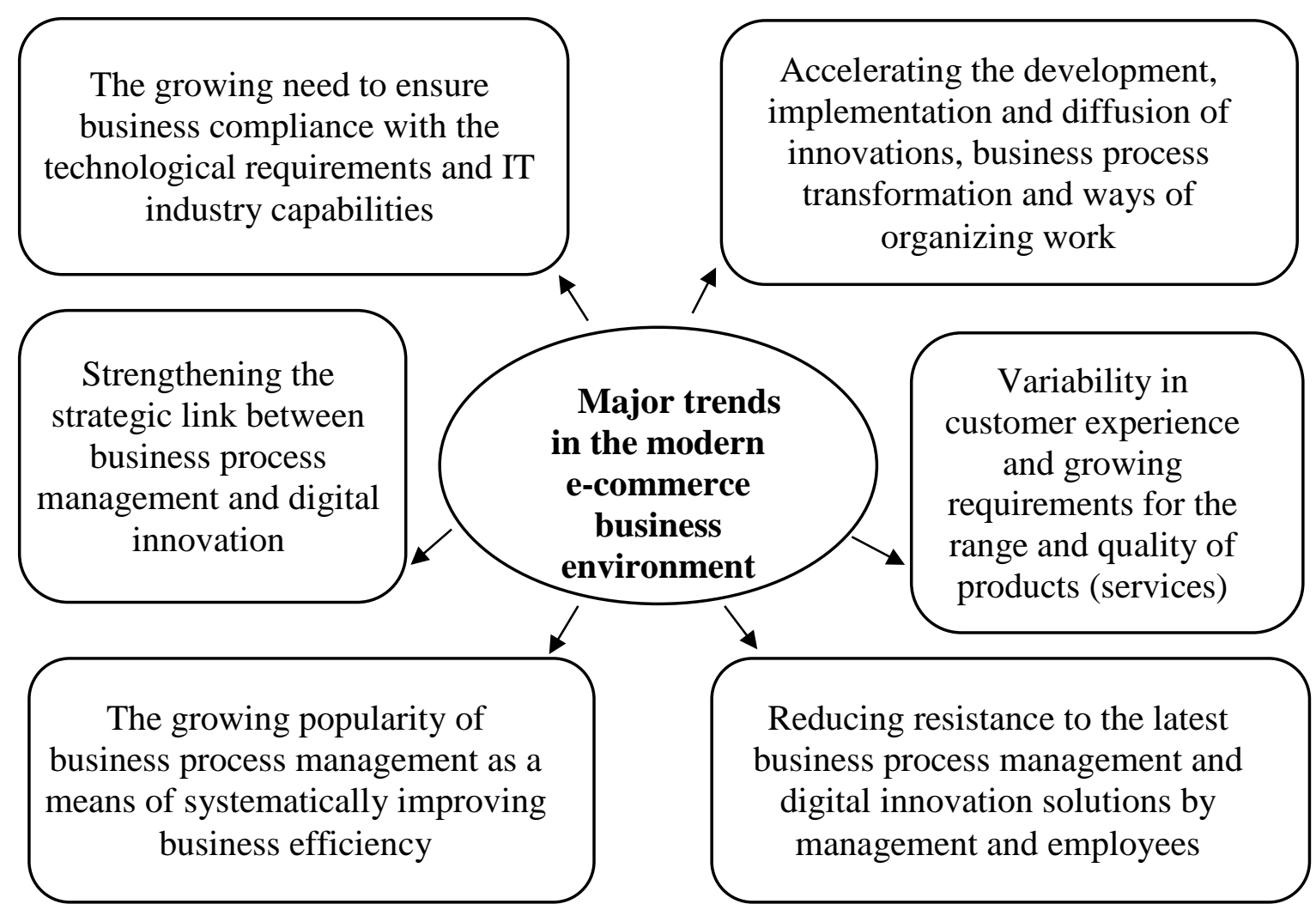

\section{Figure 1. Major trends in the modern e-commerce business environment}

Big data processing, machine learning, and artificial intelligence continue to improve customer interaction. While data processing refers to the identifying patterns in large data sets using real-time consumer data [10], machine learning involves the study and formation of algorithms and models that information systems use to perform tasks without human intervention, with machines that act in certain situations like humans. Artificial intelligence is also used to simplify decision-making and forecasting [13]. 
One of the outcomes of this trend's impact on businesses is the use of customer relationship management (CRM) systems to store and share customer information in real time.

An important trend in today's business environment is also a decrease in resistance to the latest business process management solutions and digital innovation from company management and employees. This trend has emerged as a result of reduced resistance to change by adapting corporate culture in modern organizations, in which it is increasingly popular to focus on continuous learning and improvement, introducing innovative initiatives that any employee can create. Therefore, it is forming an informed view of employees' relevance to the development of innovation processes at the company with appropriate motivational support (financial and non-financial incentives) from the company management [14].

Cultural mapping, force field analysis, metrics, and flowcharts have proven to be effective methods of change management in this context. New IT and business process management training programs confirm that change management remains helpful in addressing the barriers to developing a business process management system.

The paradigm shift from exploitative process management to research is seen as a phenomenon that should be considered in future employee development programs.

Subjective factors such as job satisfaction, performance, and engagement can be identified through the use of technology in business process management $[11 ; 14]$. In addition to the impact of digital innovation on business process management, other factors such as social and corporate culture also play a significant role in improving business processes. For example, an educated society with an open culture is less resistant to change, hence more open to disruption. Digital innovation affects social culture in a similar way.

Thus, the challenging area and the business process management tools are not only changing because of the impact of technological factors but also cultural ones, whose influence is increasing.

Research tools designed to manage business processes in an unstructured environment use knowledge to help engage employees in their improvement.

For example, research has shown that the introduction of business intelligence in business process management increases the efficiency of corporate management [8]. However, although digital process innovations help advance process analytics and outline a new generation of business process management and organizational capabilities utilizing new technologies, it is thought that such technologies will reduce human intervention in business process management [5].

The increasing strategic link between business process management and digital innovation stems from the fact that the current technological revolution is responsible for a paradigm shift towards strategically oriented business 
process management as part of a set of enterprise development strategies. While many organizations already use traditional (operational) business process management techniques, the research option can foster a culture of collaboration (e.g., in social media) and interaction between business actors (e.g., in e-commerce) to explore new ways of doing business.

However, there is an urgent need to strike a balance between operational and research business processes to achieve improved results in your organizational management [14]. This applies particularly to big data management strategies, which describe how big data can be linked to digital innovation and business process management.

The growing need to ensure business compliance with technological requirements and advances in information technology is closely related to a high potential for the use of IT capabilities for successful business development in today's highly competitive market environment. Ensuring that the business is aligned with the technology and IT capabilities relates to the need to coordinate business and IT strategy. Such alignment remains essential to the successful management of business processes in modern enterprises, for which the IT architecture is often the foundation for progressive change.

Combining an organization's IT process architecture with the entire enterprise architecture is enhanced by collaboration in each phase of the business process management lifecycle. It helps achieve faster turnaround times, better customer experience, technology transformation, IT agility, and organizational development. Furthermore, ensuring that the business is aligned with the technology and IT capabilities supports customer engagement strategies and enables implementing progressive solutions based on business and IT solutions (e.g., the adopting and developing the ecommerce practices).

The acceleration of the development, implementation and dissemination of innovations, the transformation of business processes and ways of organizing work is based, in particular, on the application of appropriate quality standards (e.g., the ISO 9000 series) to improve business processes, combining standardization in today's business environment with an awareness of the potential of information technology. At the same time, digital technologies offer the opportunity to innovate by sharing information externally (i.e., outside the organization).

The analysis of these trends in the e-commerce business environment revealed:

- the significant impact of modern information technologies on the business environment and consumer behavior, which concerns not only the purchase of certain products but also work, study, social and family relations, ecology, business, etc.;

- it is under the influence of these changes that consumers increasingly value convenience, speed, ease of transaction, and technological developments that make it easier to meet these needs, actualizing the role of 
information technology both in shaping demand for products driven by everchanging consumer needs and in creating ways to best meet those needs including through the transformation of business process management in ecommerce.

The actualization of the use of business process management as a means of systematic improvement in the efficiency of enterprises is influenced by the fact that today's business process management is increasingly moving away from the traditional (operational) approach and towards a proactive and innovative one; new technologies allow management technologies to change and become more attractive in terms of using new ways to model and monitor business processes in practice and lead to certain development trends that are specific to e-commerce as an independent area of business activity.

\section{Part 2. E-commerce trends in a competitive business environment}

The creation and spread of the Internet have produced a global business environment where the consumer has direct access to sellers. This opportunity has given rise to a powerful area of business activity, which is e-commerce. It is a system of activities aimed at carrying out transactions through electronic means of communication: telephone, fax, email, website, and the like.

In addition to the buyer-seller interaction channels used, the specificity of e-commerce consists in the fact that payment and delivery of goods and services purchased through such channels take place outside the physical store [4; 16]. Thus, advances in technology have stimulated greater awareness amongst players in relation to the market and have enabled instant interaction amongst these players in space and time, made instant transactions and information exchange possible.

The basic objectives of the functioning of economic entities in e-commerce are as follows:

1) to reduce operating costs, which increases the revenue;

2) to increase the number of products sold and increase gross profit as a result.

These objectives do not contradict, but complement each other. This is why, when studying the prerequisites for e-commerce development at the micro-level, business process management of this area becomes a subject of attention.

It should be noted that dynamic changes in the global economy, technology, consumer needs and expectations are forcing modern businesses to constantly improve the way they organize and manage their e-commerce business processes. Due to the influence of these changes, the theory, methodology, and practice of business process management are being transformed and creating new opportunities for improving business processes in specific enterprises and areas that are important for the development of modern business. 
It is, therefore, an important scientific task to investigate e-commerce trends and identify prerequisites and factors contributing to its development under certain conditions. In this context, the specificity of e-commerce business processes arises from the opportunities offered by the use of Internet technologies in the buying and selling of goods (Figure 2).

E-commerce becomes of particular importance, changing the nature, principles, and approach to doing business to a certain extent. It is necessary to mention the dramatic increase in e-commerce amid restrictions caused by COVID-19, which has increased online retail sales' share of total retail sales from $16 \%$ to $19 \%$ in 2020 , according to UNCTAD report published on May 3, 2021 [7].

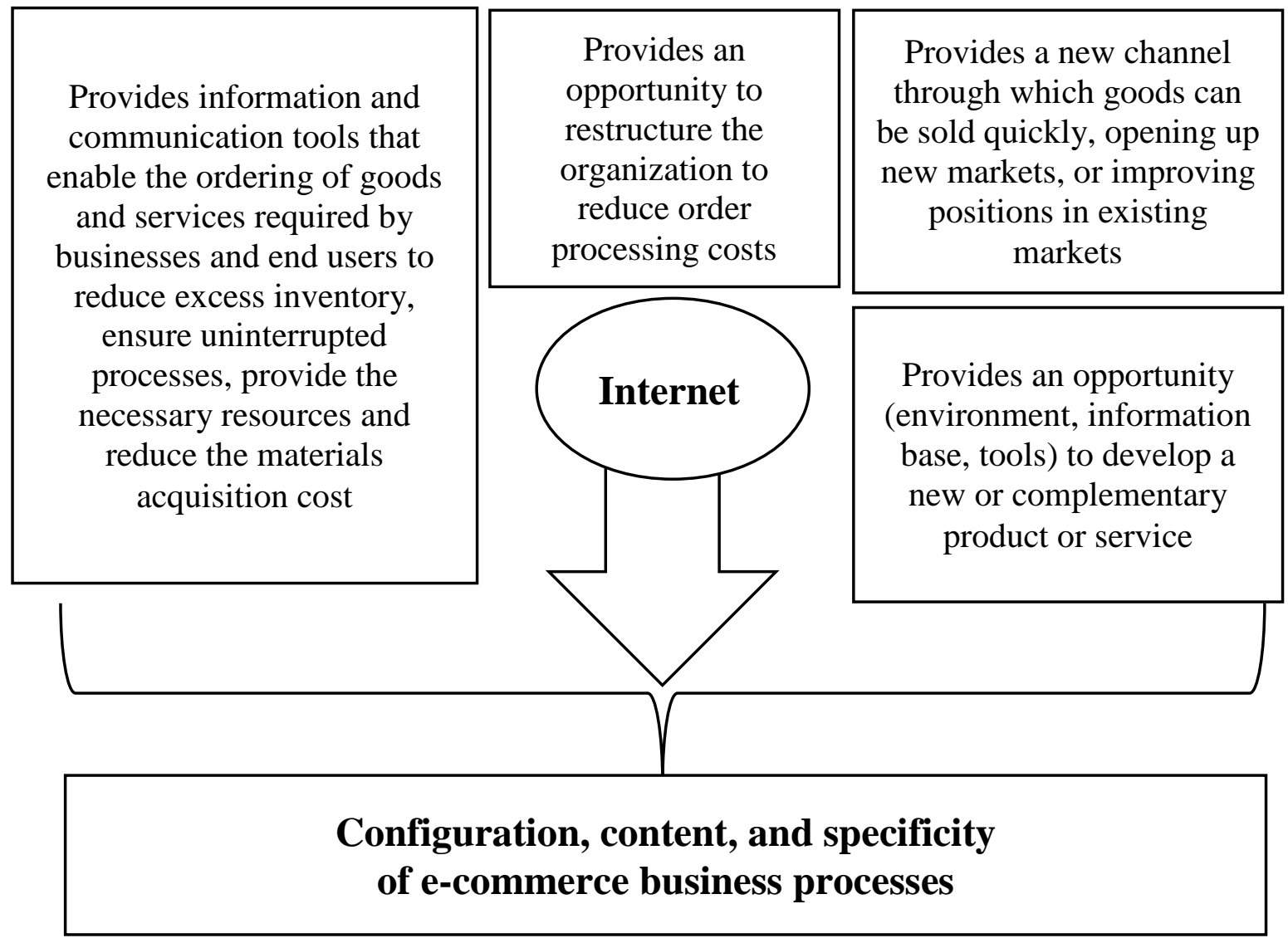

Figure 2. The impact of the Internet technologies on the e-commerce business process characteristics

Thus, the retail e-commerce market has seen a marked recovery in most of the developed world and developing countries. The highest growth rate took place in the Republic of Korea (25.9\% growth in 2020 compared to $20.8 \%$ in 2019).

Table 1 shows the e-commerce growth dynamics as a share of total retail sales in some countries, according to UNCTAD [7]. Online sales currently 
include business-to-business (B2B) and business-to-consumer (B2C) sales and are equivalent in volume to $30 \%$ of world gross domestic product (GDP).

These statistics show the growing importance of e-commerce in retail sales in developed countries. The development of e-commerce systems and the increasing relationship between these businesses and consumers have necessitated research into the factors that determine the effectiveness of user perception and management of such systems.

Table 1

Online retail sales in selected countries in 2018-2020

\begin{tabular}{|c|c|c|c|c|c|c|c|c|c|}
\hline \multirow{2}{*}{ Country } & \multicolumn{3}{|c|}{$\begin{array}{l}\text { Online retail sales } \\
\text { (billion USD) }\end{array}$} & \multicolumn{3}{|c|}{$\begin{array}{l}\text { Retail sales } \\
\text { (billion USD) }\end{array}$} & \multicolumn{3}{|c|}{$\begin{array}{l}\text { Online sales share of } \\
\text { total retail sales, \% }\end{array}$} \\
\hline & 2018 & 2019 & 2020 & 2018 & 2019 & 2020 & 2018 & 2019 & 2020 \\
\hline Australia & 13.5 & 14.4 & 22.9 & 239 & 229 & 242 & 5.6 & 6.3 & 9.4 \\
\hline Canada & 13.9 & 16.5 & 28.1 & 467 & 462 & 452 & 3.0 & 3.6 & 6.2 \\
\hline China & 1060.4 & 1233.6 & 1414.3 & 5755 & 5957 & 5681 & 18.4 & 20.7 & 24.9 \\
\hline $\begin{array}{l}\text { Republic of } \\
\text { Korea }\end{array}$ & 76.8 & 84.3 & 104.4 & 423 & 406 & 403 & 18.2 & 20.8 & 25.9 \\
\hline Singapore & 1.6 & 1.9 & 3.2 & 34 & 32 & 27 & 4.7 & 5.9 & 11.7 \\
\hline $\begin{array}{l}\text { United } \\
\text { Kingdom }\end{array}$ & 84.0 & 89.0 & 130.6 & 565 & 564 & 560 & 14.9 & 15.8 & 23.3 \\
\hline USA & 519.6 & 598.0 & 791.7 & 5269 & 5452 & 5638 & 9.9 & 11.0 & 14.0 \\
\hline
\end{tabular}

Source: adapted from [7]

In order to function and grow steadily in the marketplace, modern e-commerce businesses must build and develop their competitive advantages based on new and innovative elements. It is important for their competitiveness that the sources of competitive advantage are relatively longterm and provide advantages that are difficult for competitors to imitate, especially when economic development necessitates the rapid expansion (spread, imitation, interception) of all innovative, personalized solutions.

The dynamically changing conditions of the business environment makes it necessary to recognize that gaining and maintaining a competitive advantage in e-commerce should be seen as a continuous process based on constantly evolving solutions. Companies able to make these changes quickly will have a clear competitive advantage, and to do so, an e-commerce business model 
must first address the following to create a competitive advantage in a highly competitive business environment:

- build and maintain customer loyalty;

- develop, implement, and disseminate innovations;

- reduce the response time to changes in the business environment;

- minimize costs;

- optimize resources;

- manage risks.

Instead, competitive advantage in e-commerce is hard to gain and just as hard to maintain. This is because the Internet economy requires businesses to constantly seek out and exploit new opportunities, as opposed to using and maintaining old ones.

\section{Part 3. Transformation trends in business process management in e-commerce}

When examining the transformation of business process management in e-commerce to identify trends in such transformation under the influence of changes in the business environment, it is necessary to refer to the history of e-commerce as a business area. That will allow us to understand the stage of development this area is now and what priorities should be addressed.

Thus, based on a study of scientific papers [7; 12], the author has identified five stages of e-commerce development, as presented in Figure 3.

For the current stage of development, taking into account the trends in the influence of the business environment on the functioning of economic entities in e-commerce, it is advisable to distinguish certain specific characteristics that allow us to identify the relationship between the dynamics and specificity of the development in the past and its potential for growth in the future. These characteristics define both the opportunities and the limitations that must be taken into account in shaping the direction of e-commerce transformation.

According to the author, the characteristics of the functioning of e-commerce economic entities at the current stage include:

1) a significant cost reduction of entry into e-commerce business over the past two decades;

2) the growth of volume and usage share of mobile services and devices in total e-commerce product sales;

3) the active use of social media for brand and product promotion needs in e-commerce;

4) the growth and active usage of electronic payments (which has driven much of the development of the payment systems in general);

5) the active involvement of large retailers (that used mainly traditional sales channels) in e-commerce in order to retain the market position that e-commerce businesses are gradually occupying; 
6) making full use of e-commerce advantages and potential by small businesses, allowing them to enter the market with relatively little start-up capital;

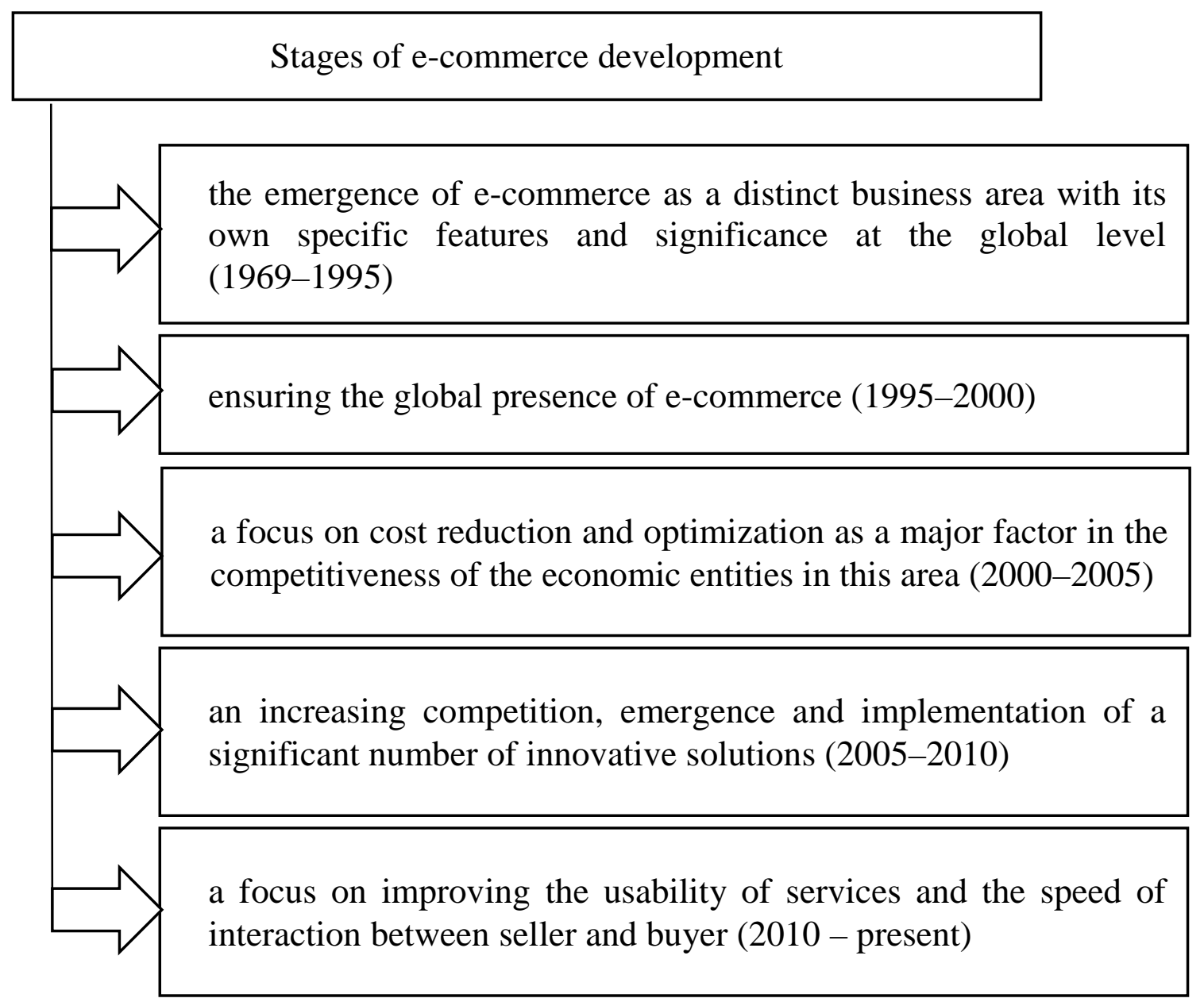

Figure 3. Stages of e-commerce development

7) the creation of new jobs in e-commerce (and reductions in traditional trade) resulting from this development is characterized by a significant level of business process automation, especially at the customer interaction level.

The above characteristics determine the conditions for the transformation of business process management in e-commerce caused by the current business trends. These conditions should be formulated as areas of transformation, certain vectors, benchmarks to build a model for the management of modern enterprises should follow it using e-commerce to ensure long-term competitiveness, sustainability, and efficiency through the maximum use of the business processes potential in e-commerce as a management object.

In the current business trend conditions, businesses that do not have a standardized, optimized process to deal with suppliers risk losing consistency 
in the supply of goods/raw materials. One of the key areas of maintaining a network of trusted suppliers is processing all elements into one consolidated business process managed by software. This is why improving supplier relationships through business process automation should be considered a promising area of business process transformation in e-commerce.

As well as automating supplier interaction, it is also important to automate the operational processes associated with e-commerce. This is because almost $80 \%$ of e-commerce processes are implemented using operational management and resource planning software. The software is not only able to automate purchases but also take into account special conditions that need to be checked (promo code, discounts, gifts on a certain date, etc.).

The automation of operational processes allows special conditions to consider determining additional fees, taxes, and special charges, ensuring efficient pricing (enabling planned profits to be made), reducing the human factor, and thereby minimizing errors. The experience of major e-commerce companies, including Amazon, has also shown the importance of streamlining return and cancellation processes.

Equally important to the transformation is the continuous improvement of customer interaction, which has become the basis for the effectiveness of modern e-commerce. Business processes should provide the ability to work quickly with databases that contain customer data, not only to solve problems that arise, but also improve the customer experience. Automation and data management make it possible to identify and analyze the relationship between certain demographics, consumer characteristics, consumer buying behavior, and ways to present it to consumers.

One more transformation trend is the integration of artificial intelligence into e-commerce businesses. This trend is characterized by the increasing use of artificial intelligence technologies to achieve greater efficiency (using fewer resources to obtain greater benefit) in the practice of both e-commerce businesses and companies in other business industries that actively use modern technologies to develop, promote, implement and sell their own products (services).

Another area of business process transformation in e-commerce is the improvement of business process monitoring and analysis procedures. Given that the development of business process management practices in ecommerce involves attention to key business aspects, from production to the sale of the final product, monitoring and analysis procedures also need to be improved. These improvements should impact the timeliness and accuracy of analytical reports, data management automation, and creating an evaluation and analytical framework that can facilitate the justification of management decisions and increase their efficiency.

Figure 4 summarizes the directions for transforming business process management in e-commerce in the context of current business trends. 
Transformation of business process management in e-commerce within the context of current trends in the business environment, aligned with these trends, will lead to increased efficiency of:

- supply, order, resource, and inventory management;

- customer service;

- application of pricing strategies;

- website management;

- product presentation;

- online business promotion.

E-commerce business process management transformation trends within the context of current business environment

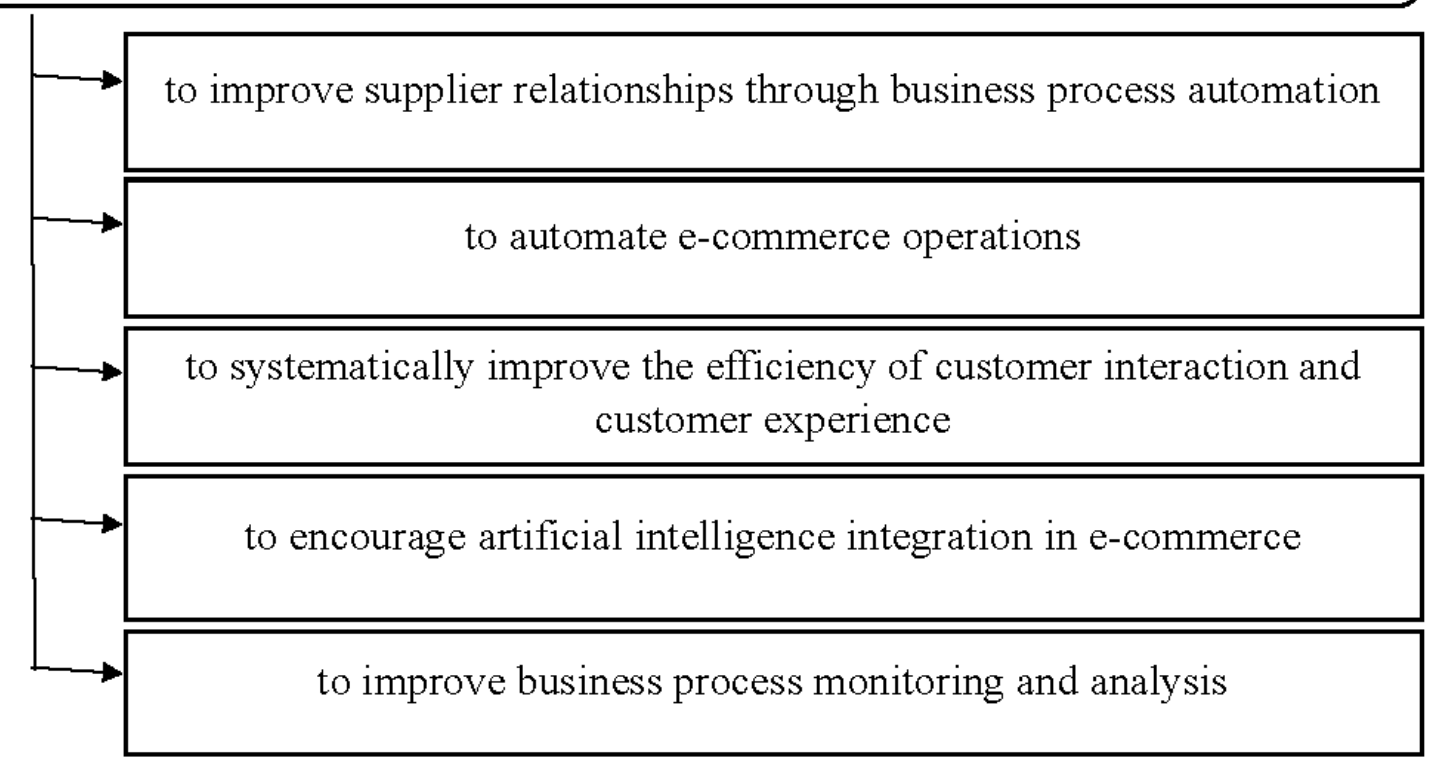

Figure 4. E-commerce business process management transformation trends within the context of current business environment

Thus, e-commerce is an area where innovations are actively implemented and disseminated. Therefore, apart from being a form of innovative entrepreneurship, it is increasingly becoming a medium for testing and implementing innovations that improve the efficiency of business processes and contribute to the success of businesses as a whole.

\section{Conclusions}

The study focuses on ensuring the effective transformation of business process management in e-commerce in the context of identified trends in today's business environment. It is determined that under the influence of certain trends, limitations, and new opportunities, modern business is increasingly paying attention to the potential of e-commerce as a highly profitable and dynamic area. As a result, business process management 
improvements in this area are also in demand and should become a way for modern companies to build and maintain a competitive advantage at the organizational and management level.

In this context, a key step in improving the business process management in e-commerce is the development of strategic directions, certain vectors, benchmarks to build a model to which the management system of a modern ecommerce company should aim to ensure long-term competitiveness, sustainability, and efficiency by maximizing the potential of e-commerce business processes as an object of management.

It is shown that the development of the Internet has determined the dynamics and variability of the use of leading technological solutions in ecommerce and has driven the rapid evolution of e-commerce over the past three decades from an experimental channel for product promotion/sales into a powerful business sphere, to some extent displacing much of the traditional global trade.

The analyzed trends in the influence of the business environment on the functioning of economic entities of e-commerce, along with the characteristics of modern e-commerce highlighted by the author, allow us to present the relationship between the dynamics and specificity of its development in the past and the potential for its development in the future. These characteristics are taken into account when developing the transformation trends of business process management in e-commerce within the context of the modern business environment, which are: to improve the supplier relationships through business process automation; to automate ecommerce operations; systematically improve the efficiency of customer interaction and customer experience; to encourage the integration of artificial intelligence in e-commerce, and improve business process monitoring and analysis.

\section{References:}

1. 75 Essential Ecommerce Statistics: 2020/2021 Data and Market Share Analysis. FinancesOnline. Available at: https://financesonline.com/40-essential-ecommercestatistics-2019-analysis-of-trends-data-and-market-share/ (accessed 09 June 2021).

2. Amazon Flirts With \$1 Trillion Value Amid 8-Day Rally Streakhttps. Available at: https://www.bloomberg.com/news/articles/2019-07-10/amazon-back-on-cusp-of-1-trillionvaluation-after-7-day-streak (accessed 09 June 2021).

3. Balyk U. O., Kolisnyk M. V. (2014) Elektronna komertsiya yak element systemy svitovoho hospodarstva [E-commerce as an element of the world economy]. Bulletin of the National University «Lviv Polytechnic», no. 811, pp. 11-19.

4. Chuchko N. O., Lozikova G. M. (2011) Elektronna torhivlya V systemi svitohospodars'kykh vidnosyn [E-commerce in the system of world economic relations]. Industrial economics, no. 4, pp. 153-158.

5. Davenport T. H. (1993) Process Innovation: reengineering work through information technology. Boston, Mass.: Harvard Business School Press, 337 p. 
6. Drazhnytsia S. A., Zaburmekha E. M. (2018) Elektronna komertsiya: svitovi trendy ta prohnoz rozvytku v Ukrayini [E-commerce: global trends and development forecast in Ukraine]. Bulletin of Khmelnytsky National University, no. 5, pp. 69-73.

7. Global e-commerce jumps to \$26.7 trillion, COVID-19 boosts online sales / UNCTAD. Available at: https://unctad.org/news/global-e-commerce-jumps-267-trillioncovid-19-boosts-online-sales (accessed 09 June 2021).

8. Interesting facts about Internet commerce in the world in 2018. Available at: http://lemarbet.com/ua/razvitie-internet-magazina/interesnye-fakty-ob-internet-torgovle/ (accessed 09 June 2021).

9. Kovtun T. D., Matvienko A. P. (2020) Suchasnyy stan i perspektyvy rozvytku svitovoho ta vitchyznyanoho rynkiv elektronnoyi komertsiyi [Current state and prospects of development of world and domestic e-commerce markets]. Business Inform, no. 4, pp. 295-303.

10. Lazebnyk L. L. (2018) Digitalization of economic relations as a factor in improving the business processes of the enterprise [Didzhytalizatsiya ekonomichnykh vidnosyn yak faktor udoskonalennya biznes-protsesiv pidpryyemstva]. Economic Bulletin. Seriya: finansy, oblik, opodatkuvannya, no. 2.

11. Levitska Ya. V. (2020) Suchasnyy stan didzhytalizatsiyi u biznes-seredovyshchi [The current state of digitalization in the business environment. Proceedings of the All-Ukrainian scientific-practical Internet conference. Available at: https://pnu.ua/sites/ default/files/attach/2019/12408/zbirnyk_nu_lp_2020_biznes.pdf (accessed 09 June 2021).

12. Moore K. Ecommerce $101+$ The History of Online Shopping: What The Past Says About Tomorrow's Retail Challenges. Available at: https://www.bigcommerce.com/blog/ ecommerce/\#ecommerce-timeline (accessed 09 January 2021).

13. Osmundsen K., Iden J., Bygstad B. (2018) Digital transformation: drivers, success factors, and implications, The 12th Mediterranean Conference on Information Systems (MCIS), Corfu, Greece, 105.

14. Ustenko M. O and Ruskikh A. A. (2019) Didzhytalizatsiya: osnova konkurentospromozhnosti pidpryyemstva $\mathrm{v}$ realiyakh tsyfrovoyi ekonomiky [Digitalization: the basis of enterprise competitiveness in the realities of digital economy]. Bulletin of Transport Economics and Industry, no. 68. (in Ukrainian)

15. Yatsenko O. M., Gryazina A. S., Shevchyk O. O. (2019) Elektronna komertsiya yak element hlobalnoyi torhovelnoyi systemy [E-commerce as an element of the global trading system]. Current economic problems, no. 8, pp. 4-15.

16. Yudin O. M., Makarova M. V., Lavreniuk R. M. (2011) Systemy elektronnoyi komertsiyi: stvorennya, prosunennya i rozvytok [E-commerce systems: creation, promotion and development]. Poltava: RVV PUET. (in Ukrainian) 